\title{
Interactions of Valeriana officinalis L. and Passiflora incarnata $L$. in a patient treated with lorazepam
}

\begin{tabular}{|r|l|}
\hline Journal: & Phytotherapy Research \\
\hline Manuscript ID: & PTR-09-0195.R1 \\
\hline Wiley - Manuscript type: & Letter to the Editor \\
\hline Date Submitted by the & 04-Mar-2009 \\
\hline Complete List of Authors: & $\begin{array}{l}\text { Carrasco, María Consuelo; Servicio Extremeño de Salud, Centro de } \\
\text { Salud Pueblonuevo del Guadiana } \\
\text { Vallejo, José Ramón; Universidad de Extremadura, Facultad de } \\
\text { Medicina (Historia de la Medicina) } \\
\text { Pardo-de-Santayana, Manuel; Universidad Autónoma de Madrid, } \\
\text { Biologia (Botánica) } \\
\text { Peral, Diego; Universidad de Extremadura, Facultad de Medicina } \\
\text { (Historia de la Medicina) } \\
\text { Martín, Miguel Ángel; Universidad de Extremadura, Facultad de } \\
\text { Medicina (Historia de la Medicina) } \\
\text { Altimiras, Jacinto; Universidad de Extremadura, Facultad de } \\
\text { Medicina (Historia de la Medicina) }\end{array}$ \\
\hline Keyword: & $\begin{array}{l}\text { benzodiazepines, herbal remedies, interactions, valerian, } \\
\text { passionflower }\end{array}$ \\
\hline \hline
\end{tabular}

\section{(s) ScholaroNE" \\ Manuscript Central}




\title{
LETTER TO THE EDITOR
}

\section{Interactions of Valeriana officinalis L. and Passiflora incarnata L. in a patient} treated with lorazepam

María Consuelo Carrasco ${ }^{1}$, José Ramón Vallejo ${ }^{2}$, Manuel Pardo-de-Santayana ${ }^{3}$, Diego Peral ${ }^{2}$, Miguel Ángel Martín², Jacinto Altimiras ${ }^{2}$

\author{
${ }^{1}$ Consultorio Local Nuestra Sra. de la Soledad de Guadiana del Caudillo. Centro \\ de Salud Pueblonuevo del Guadiana (Badajoz). Travesía de la Constitución s/n. \\ 06184 Pueblonuevo del Guadiana. (Badajoz). Spain \\ ${ }^{2}$ Grupo de Investigación en Humanidades Médicas. Facultad de Medicina. \\ Universidad de Extremadura. Avda. de Elvas s/n. 06071 Badajoz. Spain. \\ ${ }^{3}$ Departamento de Biología (Botánica). Universidad Autónoma de Madrid. c/ \\ Darwin 2. Campus de Cantoblanco, 28049 Madrid. Spain. \\ Corresponding author: \\ Manuel Pardo de Santayana. Departamento de Biología (Botánica). Universidad \\ Autónoma de Madrid. c/ Darwin 2. Campus de Cantoblanco, E-28049 Madrid; e-mail: \\ manuel.pardo@uam.es; phone: 0034+914978110; fax: 0034+914978344
}




\title{
Interactions of Valeriana officinalis L. and Passiflora incarnata L. in a patient
} treated with lorazepam

MC Carrasco, JR Vallejo, M Pardo-de-Santayana, D Peral, MA Martín, J

Altimiras

\begin{abstract}
There is an increasing interest in the health risks related to the use of herbal remedies. Although most consumers think that phytomedicines are safe and without side-effects, interactions between complementary alternative-and-conventional medicines are being described.
\end{abstract}

The aim of this clinical-case-report is to highlight the importance of the safe use of herbal remedies by providing a clinical interaction study between pharmaceutical medicines and herbal medicinal products.

The case of a patient self-medicated with Valeriana officinalis L. and Passiflora incarnata $\mathrm{L}$. while he was on lorazepam treatment is described. Handshaking, dizziness, throbbing and muscular fatigue were reported within the 32 hours before clinical diagnosis. The analysis of family medical history ruled out essential tremor, Parkinson's disease, Wilson's disease and other symptom-related pathologies. His medical history revealed a Generalized Anxiety Disorder and medicinal plant consumption but no neurological disorder. Appropriate physical examination was carried out.

An additive or synergistic effect is suspected to have produced these symptoms. Valerian and passionflower active principles might increase the inhibitory activity of Deleted: ra benzodiazepines binding to the GABA receptors, causing severe secondary effects. 
Due to the herbal-product-self-medication increase, the use of herbal remedies should be registered while taking personal clinical history. Multidisciplinary teams should be created to raise studies on medicinal plants with impact on medical praxis.

Keywords: herbal remedies, interactions, benzodiazepines, valerian, passionflower,

\section{Introduction}

The simultaneous consumption of medicaments and herbal remedies (including dry or fresh medicinal plants and phytopharmaceuticals or vegetable drugs), might cause interactions, much of which are not described nowadays (Farah et al., 2000).

Nowadays, there is an increasing interest on health risks related to the use of herbal remedies. There is uncertainty with regard to their quality, safety and efficacy. Besides, the increasing trend of self-medication and consumers' perception that phytopharmaceuticals are always safe and have no side-effects, can lead to an increase of the incidence of adverse effects associated to the consumption of herbal medicines (Elvin-Lewis, 2005; Williamson, 2005).

During the visit to the general practitioner in Guadiana del Caudillo (Badajoz, Spain), we reported a clinical case (not previously described in available scientific literature) of a 40 years old male patient self-medicated with valerian (Valeriana officinalis L.) and passionflower (Passiflora incarnata L.) while on lorazepam treatment.
Deleted: Primary Health Attention team considers the benefits of registering these remedies' use in

Deleted: flora
Deleted: ay

Deleted: There are two different types of interactions: a) Pharmacokinetic interactions which are based in the decrease of medicine absorption, its metabolizing or its elimination process, b) Pharmacodynamic interactions that provoke additive, synergistic or antagonistic effects (Castillo and Martínez, 2007). 


\section{Results: Clinical Case}

Handshaking, dizziness, throbbing and muscular fatigue were reported within the 32 hours before clinical diagnosis. No other neurological symptoms such as cephalea, paresthesia, loss of any extremity strength neither language nor walking gait alterations were reported.

Family medical history ruled out essential tremor, including Parkinson's and Wilson's disease. Clinical history revealed a generalized anxiety disorder (GAD) and dream disorders. No endocrine-metabolic pathologies, hepatopathies, nephropathies, breathing problems neither personal history of neurological pathologies, consumption of toxic substances, high blood pressure or drug allergies were reported. The patient only mentioned that he had recently consumed medicinal plants.

Since two months ago and without side effects, the patient was following a $2 \mathrm{mg} / 24 \mathrm{~h}$ lorazepam treatment. Approximately two hours before bedtime and during two days in a row, the patient took the infusion of valerian subterranean parts. Just before going to bed the patient took the same infusion mixed with unlimited-quantity of passionflower dry herb without side effects. The estimated dose for an infusion is 300 mg. Instead of taking an infusion, the third day before going to bed, the patient took a similar dose of the plants but in tablets of dry extract from valerian rhizomes and roots and aerial parts of passionflower, Each tablet contained $300 \mathrm{mg}$ of valerian and $380 \mathrm{mg}$ of passionflower extract according to the product label. The patient took three tablets at

one-hour intervals before going to sleep. Nerves and light-and-rhythmical shaking disappeared shortly after going to bed, followed by a strong drowsiness. As the fourth day the phytopharmaceutical treatment was repeated, strong handshaking, dizziness and palpitations appeared before going to bed, followed by a heavy drowsiness which made 
him fall asleep.

\section{Discussion and Conclusions}

Lorazepam and other benzodiazepines are described as causing-and-aggravating druginduced tremor (Sweetman, 2006). Moreover, although valerian drug have low toxicity, when their intake exceeds 20 times the 2-3 g therapeutic doses, intoxication takes place. Its symptoms that include handshaking or fatigue, abdominal cramps, chest tightness, dizziness and mydriasis, disappear within 24 hours (Villar del Fresno and Carretero, 2001; Willey et al., 1995). 
The examined patient suffered from excessive drowsiness and dizziness, which can be related to the increase in the sedative effect of valerian observed in animal's clinical trials that had been previously treated with benzodiazepines and other barbiturics. No valerian-benzodiazepine human-related interactions had been previously reported (Castillo and Martínez, 2007).

However interactions between benzodiazepines (alprozolam) and sedative plants such as kava (Piper methysticum G. Forst.) have been already described (Almeida and Grimsley, 1996).

Passionflower drug, normally prescribed for the treatment of anxiety and insomnia, has a sedative effect that may also increase when combined with other sedative drugs. It provokes nausea and dizziness when doses are high (Castillo and Martínez, 2007). This was one of the patient's symptoms.

It can be suspected that the symptoms of the case were caused by an interaction between the herbal remedies and lorazepam. The symptoms disappeared when the patient stopped the herbal treatment. An additive or synergistic effect on the central nervous system (CNS) is suspected to have produced these symptoms. Benzodiazepines facilitate the inhibitory neurotransmitter gamma-aminobutyric acid (GABA) by binding to the alpha subunit of the GABA receptor (Bowery and Smart, 2006). Valerian and passionflower might increase the inhibitory activity of benzodiazepines binding to the Deleted: ra GABA receptors, causing severe secondary effects as well.

Due to the increase in the use of herbal remedies, it seems advisable for the general practitioners to ask on the habit of consuming these remedies while taking personal history and anamnesis. This could be a difficult task, since many patients hide 


\section{References}

Almeida JC, Grimsley EW. 1996. Coma from the Health Food Store: Interaction between Kava and Alprazolam. Ann Intern Med 125: 940-941

Bowery NG, Smart TG. 2006. GABA and glycine as neurotransmitters: a brief history. Br J Pharmacol 147(S1): S109-S119

Castillo E, Martínez I. 2001. Manual de Fitoterapia. Elsevier, Masson: Madrid.

Elvin-Lewis, M. 2005. Safety Issues Associated with Herbal Ingredients. Adv Food Nutr Res 50: 219-313.

Farah MD, Edwards R, Linquist M, Leon C, Shaw D. 2000. International Monitoring of Adverse Health Effects Associated with Herbal Medicines. Pharmacoepidemiol Drug Saf 9: 105-112. 
Sweetman SC (ed). 2006. Martindale: Guía Completa de Consulta Farmacoterapéutica. 2nd Spanish ed. Pharma: Barcelona. Translation of the 33rd ed of "Martindale: the complete drug reference".

Villar del Fresno AM, Carretero E. 2001. Valeriana officinalis. Fitoquímica, farmacología y terapéutica. Farm Prof 10: 98-106.

Willey LB, Mady SP, Cobaugh DJ, Wax PM. 1995. Valerian Overdose: A Case Report. Vet Hum Toxicol 37(4): 364-365.

Deleted: Vallejo JR, Pardo-deSantayana M, Peral D, Carrasco MC, López D. 2008a. Uso medicinal de Atractylis gummifera L. en Guadiana del Caudillo (Badajoz, España). Toxicidad y especies afines. Rev Fitoterapia 8(2): 161-169. II

Vallejo JR, Peral D, Carrasco MC

2008b. Catálogo de remedios de la medicina popular de Guadiana del

Williamson EM. 2005. Interactions between Herbal and Conventional Medicines. Expert Opin Drug Saf 26(15):1075-1092. 